\title{
Relation between Epicardial Adipose Tissue Thickness Assessed by Multidetector Computed Tomography and Significance of Coronary Artery Disease
}

\author{
Neveen I. Samy', Mohammad Fakhry ${ }^{2,3}$, Walaa Farid ${ }^{1}$ \\ ${ }^{1}$ Cardiology Department, Faculty of Medicine Menoufia University, Menoufia, Egypt \\ ${ }^{2}$ Nasser Institute, Cairo, Egypt \\ ${ }^{3}$ Dabbous Cardiac Centre, Al Adan Hospital, Kuwait City, Kuwait \\ Email: neveinsami@yahoo.com
}

How to cite this paper: Samy, N.I., Fakhry, M. and Farid, W. (2020) Relation between Epicardial Adipose Tissue Thickness Assessed by Multidetector Computed Tomography and Significance of Coronary Artery Disease. World Journal of Cardiovascular Diseases, 10, 91-101.

https://doi.org/10.4236/wjcd.2020.102011

Received: December 24, 2019

Accepted: February 18, 2020

Published: February 21, 2020

Copyright $\odot 2020$ by author(s) and Scientific Research Publishing Inc. This work is licensed under the Creative Commons Attribution International License (CC BY 4.0).

http://creativecommons.org/licenses/by/4.0/

\begin{abstract}
Objective: To evaluate the relation between epicardial adipose tissue (EAT) thickness and also pericoronary fat assessed by Multidetector Computed Tomography (MDCT) with both calcium score and significance of coronary artery disease. Background: Epicardial adipose tissue (the visceral fat of the heart present under the visceral layer of the pericardium) has the same origin of abdominal visceral fat, which is known to be strongly related to the development of coronary artery atherosclerosis. Multidetector CT (MDCT) provides an accurate and reproducible quantification of EAT due to its high spatial and temporal resolution. Patients and Methods: The current study included 70 patients with low-intermediate probability of coronary artery disease. All patients were subjected to 256 Multidetectors CT to assess EAT thickness, the mean thickness of the pericoronary fat surrounding the three coronary arteries and coronary calcium score. Also coronary CT angiography was done and patients were then divided into 3 groups according to significance of coronary atherosclerosis: Group 1: No atherosclerosis (20 patients), Group 2: Non obstructive atherosclerosis (luminal narrowing less than $50 \%$ in diameter) (25 patients), Group3: Obstructive atherosclerosis (luminal narrowing $\geq 50 \%$ ) (25 patients). Results: The mean EAT thickness and the mean pericoronary fat thickness were significantly higher in patients with obstructive coronary artery disease (CAD) with stenosis $>50 \%$ (group 3) compared to other groups with normal coronaries or non obstructive (CAD). ROC curve was used to define the best cut off value of the thickness of both EAT and pericoronary fat in predicting the obstructive CAD group which was $\geq 7.2$ and $12.6 \mathrm{~mm}$ for epicardial and pericoronary fat respectively. Also there is a
\end{abstract}


positive correlation between both epicardial adipose tissue and pericoronary fat thickness and the coronary calcium score. Conclusion: EAT thickness and pericoronary fat thickness can be used in predicting the significance of coronary artery disease.

\section{Keywords}

Coronary Artery Disease, Multi Detector Computed Tomography, Coronary

CT Angiography, Epicardial Adipose Tissue Thickness, Pericoronary Fat Thickness

\section{Introduction}

Coronary artery disease (CAD) is the leading cause of death and a major cause of morbidity worldwide [1]. Several risk factors have been found to be associated with CAD. Substantial evidence has demonstrated that visceral obesity is an independent risk factor for CAD [2] [3]. Epicardial adipose tissue (being the visceral fat of the heart present under the visceral layer of the pericardium) has the same origin as that of abdominal visceral fat, which is found to be significantly related to the occurrence of coronary artery disease (CAD).

EAT (a main source of free fatty acids and some inflammatory cytokines) thickness represents visceral adiposity rather than general obesity. It correlates with metabolic syndrome, insulin resistance, subclinical atherosclerosis and $\mathrm{CAD}$, and could be used as a simple tool for cardiometabolic risk prediction [4].

Multidetector CT provides an accurate and reproducible method to measure EAT thickness due to its high spatial and temporal resolution [5].

Previous studies have shown strong correlation between EAT and coronary calcium score as well as cardiac events [6] [7] [8] [9].

Therefore, measurement of EAT thickness by CT is considered a non-invasive tool which can help in risk stratification of patients with coronary artery disease.

So this study aimed at assessment of the relationship between EAT thickness and also pericoronary fat measured by multidetector computed tomography with coronary calcium score and significance of coronary artery disease.

\section{Methods}

The current study included 70 Patients with suspected coronary artery disease (Low -intermediate probability) defined according to Diamond and Forrester pre-Test probability of coronary artery disease by age, sex, and symptoms as shown in Table 1. (Diamond \& Forrester, 1979) [10] referred for CT coronary angiography at Dabbous cardiac centre, Al Adan hospital, Kuwait between the period of February 2017 to September 2017.

Patients with renal insufficiency ( $\mathrm{S}$. creatinine $>1.5 \mathrm{mg} / \mathrm{dl}$ ), previous history of PCI or previous CABG and also patients who have difficulties in performing $\mathrm{CT}$, like inadequate breath holding and heart failure were excluded from the 
Table 1. Diamond and for rester pre-test probability of coronary artery disease by age, sex, and symptoms.

\begin{tabular}{ccccc}
\hline $\begin{array}{c}\text { Age } \\
\text { (years) }\end{array}$ & Sex & $\begin{array}{c}\text { Typical/Definite angina } \\
\text { pectoris }\end{array}$ & $\begin{array}{c}\text { Atypical/probable angina } \\
\text { pectoris }\end{array}$ & $\begin{array}{c}\text { Nonanginal chest } \\
\text { pain }\end{array}$ \\
\hline \multirow{2}{*}{$\leq 39$} & Men & Intermediate & Intermediate & Low \\
& Women & Intermediate & Very low & Very low \\
$40-49$ & Men & High & Intermediate & Intermediate \\
& Women & Intermediate & Low & Very low \\
$50-59$ & Men & High & Intermediate & Intermediate \\
& Women & Intermediate & Intermediate & Low \\
$\geq 60$ & Men & High & Intermediate & Intermediate \\
& Women & High & Intermediate & Intermediate \\
\hline
\end{tabular}

High: $>90 \%$ pre-test probability. Intermediate: between $10 \%$ and $90 \%$ pre-test probability. Low: between $5 \%$ and $10 \%$ pre-test probability. Very low: $<5 \%$ pre-test probability.

study. All patients were subjected to detailed medical history taking, full Clinical examination, 12 leads ECG and routine blood investigations.

Using GE Revolution 256 Multidetectors CT coronary angiography was done, Patients with a heart rate $>70$ beats per minute received oral metoprolol (25 - 50 $\mathrm{mg}$ ) or ivabradine $(2.5-5 \mathrm{mg})$ before the study. All scans were preceded by non-contrast enhanced scan for coronary calcium score (sequential scan with 32 $\times 0.6 \mathrm{~mm}$ collimation, tube current $60 \mathrm{mAs}$ at $120 \mathrm{kV}$ ), this was done to rule out patients with dense coronary calcification (total score above 1000). All included patients received intravenous nonionic iso-osmolar contrast medium (visipaque $320 \mathrm{mg} / \mathrm{mL}$ ) using the test bolus technique with a bolus of $10 \mathrm{ml}$ of the contrast agent was injected intravenously at a rate of $(5 \mathrm{ml} / \mathrm{s})$ followed by $50 \mathrm{ml}$ saline in antecubital vein and then acquisition of sequence of images at the level of the Aorta and Pulmonary arteries every two seconds. then After accurate calculation of delay time from start of injection till maximum intensity of dye in the Aorta and checking the ECG trigger, images acquisition is done after injection of $60 \mathrm{ml}$ visipaque $320 \mathrm{mg} / \mathrm{mL}$ at flow rate $6 \mathrm{ml} / \mathrm{sec}$ followed by $60 \mathrm{ml}$ saline at flow rate 6 $\mathrm{ml} / \mathrm{sec}$ using power injector or infusion syringe. Assessment of the severity of lesions done by [11]:

1) Visual assessment: The degree of luminal reduction compared to the reference diameter in axial and oblique views.

2) Quantative assessment: Curved multiplane reconstruction. Computed tomography datasets were transferred to an offline workstation (ADVANCED WORKSTATION) for image analysis.

Patients were divided into 3 groups: Group 1: No atherosclerosis (20 patients), Group 2: Non obstructive atherosclerosis (luminal narrowing $<50 \%$ in diameter) (25 patients), Group 3: Obstructive atherosclerosis (luminal narrowing $\geq$ 50\%) (25 patients).

Full EAT thickness measurements were done in the most motionless phase of 
the cardiac cycle, which was usually the mid-diastolic phase, with retrospective cardiac gating at $70 \%-80 \%$ of the R-R interval. Measurements were performed at the basal level of the ventricles on short-axis views. Three EAT thickness measurements were made (inferior, center, and superior) corresponding to measurements at the $25 \%, 50 \%$ and $75 \%$ level of the RV wall, respectively, perpendicular to the surface of the heart from the visceral epicardium to the outside of the myocardium. The mean of the three measurements (referred to as epicardial adipose tissue "EAT") was used for the analyses [12]. Regarding pericoronary fat thickness $(\mathrm{mm})$, measurements were done on images where the axial sections were perpendicular to the surface of the heart. In each of the regions of the left anterior descending artery (LAD), and left circumflex (LCX) and right coronary artery (RCA), the maximum fat thickness, assessed as the largest distance from the myocardium to the visceral epicardium was measured. The mean thickness of the pericoronary fat surrounding the three coronary arteries was used to measure the pericoronary fat thicknesses, illustrated in Figure 1.

Data were analyzed using IBM SPSS 23.0 for windows (SPSS Inc., Chicago, IL, USA) and NCSS 11 for windows (NCSS LCC., Kaysville, UT, USA). Also Receiver

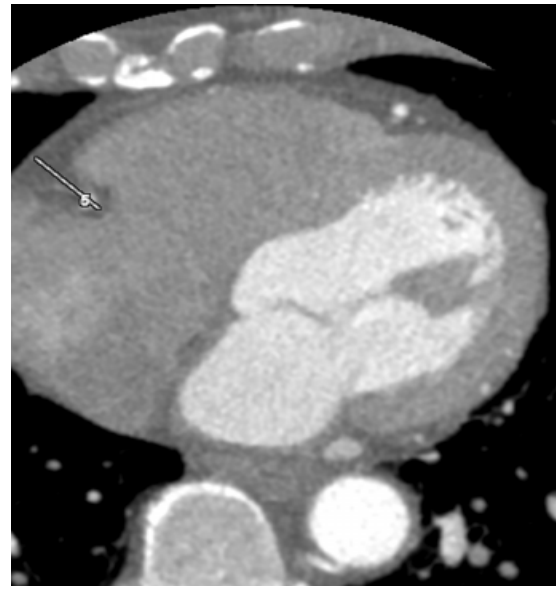

(A)

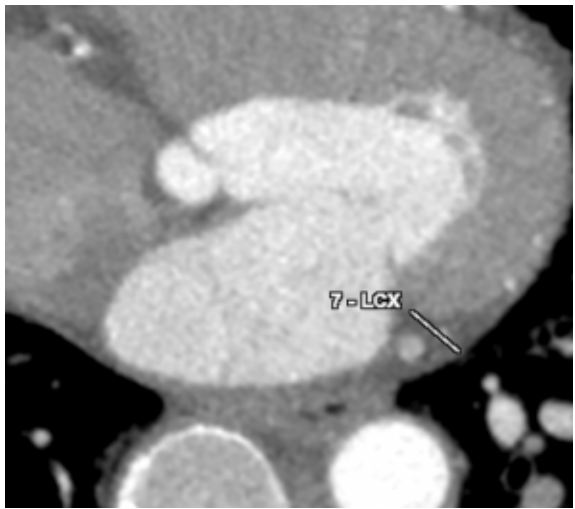

(C)

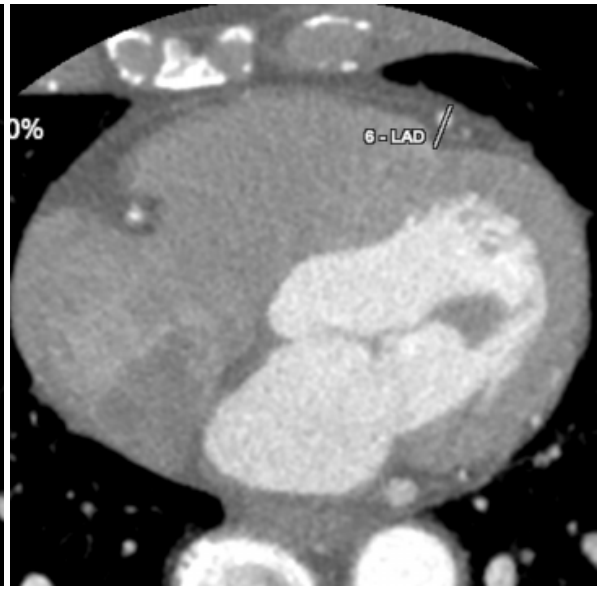

(B)

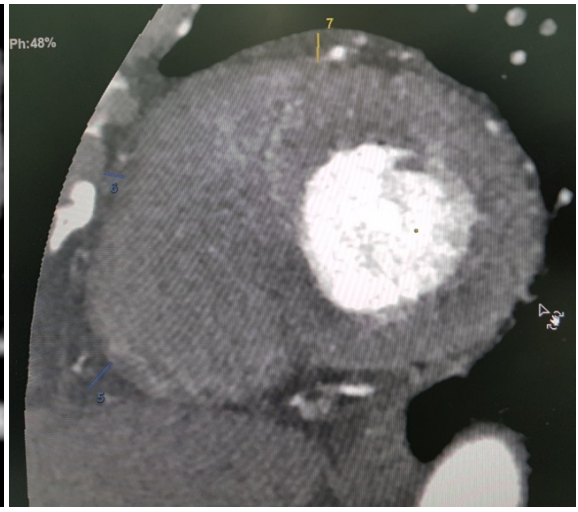

(D)

Figure 1. Demonstration of epicardial adipose tissue thickness and pericoronary fat thickness. (A) Pericoronary fat around RCA, (B) Pericoronary fat around LAD, (C) Pericoronary fat around LCX, (D) Epicardial Fat. 
operating characteristic (ROC) curve analysis was used to identify optimal cut-off values. The following tests were done: A one-way analysis of variance (ANOVA) was used when comparing between more than two means if data is normally distributed, Kruskal-Wallis test used when the normality, homogeneity of variances, or outliers' assumptions for One-Way ANOVA are not met. Chi-square $\left(\mathrm{X}^{2}\right)$ test of significance was used in order to compare proportions between two qualitative parameters and Spearman's correlation coefficient (r) test was used for correlating data.

\section{Results}

Out of the 70 patients $45(64.3 \%)$ were males and 25 (35.7\%) were females. The mean age of the patients was $50.6 \pm 9.3$ with significant difference between groups. 19 (27.1\%) patients have diabetes mellitus with higher incidence (statistically significant) in group $2(40 \%)$ and $3(32 \%)$ compared to group 1 (5\%).

There was a statistically significant higher $\mathrm{Ca}$ score in patients with $\mathrm{DM}$, hypertension and smoking compared to patients without these risk factors. On the other hand, there was no statistically significant difference in patients with other risk factors (dyslipidemia, obesity, positive family history of premature coronary artery disease) compared to patients without these risk factors (Table 2).

There was slight increase (statistically nonsignificant) in EAT thickness in patients with risk factors (hypertension, DM, smoking, obesity, positive family history of premature coronary artery disease). Also there was slight increase

Table 2. The relationship between risks factors and Ca score, EAT thickness (mm) and PCFT (mm).

\begin{tabular}{|c|c|c|c|c|c|c|c|c|c|c|c|}
\hline \multirow{2}{*}{ Risk factor } & & \multirow{2}{*}{ Count (\%) } & \multicolumn{3}{|c|}{ Ca score } & \multicolumn{3}{|c|}{ EAT thickness $(\mathrm{mm})$} & \multicolumn{3}{|c|}{ PCFT (mm) } \\
\hline & & & Mean \pm SD & Z-value • & P-value & Mean \pm SD & Z-value • & P-value & Mean \pm SD & Z-value • & $\mathrm{P}$-value \\
\hline HTN & $\begin{array}{l}\text { No } \\
\text { Yes }\end{array}$ & $\begin{array}{l}38(54.3 \%) \\
32(45.7 \%)\end{array}$ & $\begin{array}{r}90.2 \pm 254.5 \\
187.2 \pm 355.9\end{array}$ & -2.634 & $0.008(S)$ & $\begin{array}{l}7.0 \pm 2.1 \\
7.9 \pm 2.5\end{array}$ & -1.357 & $\begin{array}{l}0.175 \\
\text { (NS) }\end{array}$ & $\begin{array}{l}12.4 \pm 2.2 \\
12.8 \pm 2.7\end{array}$ & -0.724 & $\begin{array}{l}0.472 \\
\text { (NS) }\end{array}$ \\
\hline $\mathrm{DM}$ & No & $\begin{array}{l}51(72.9 \%) \\
19(27.1 \%)\end{array}$ & $\begin{array}{l}91.5 \pm 287 \\
249.9 \pm 335\end{array}$ & -2.764 & $0.006(S)$ & $\begin{array}{l}7.2 \pm 2.4 \\
7.8 \pm 2.1\end{array}$ & -1.275 & $\begin{array}{l}0.202 \\
(\mathrm{NS})\end{array}$ & $\begin{array}{l}7.2 \pm 2.4 \\
7.8 \pm 2.1\end{array}$ & -1.175 & $\begin{array}{l}0.244 \\
\text { (NS) }\end{array}$ \\
\hline Smoking & $\begin{array}{l}\text { No } \\
\text { Yes }\end{array}$ & $\begin{array}{l}55(78.6 \%) \\
15(21.4 \%)\end{array}$ & $\begin{array}{c}95.4 \pm 226.2 \\
278.1 \pm 487.6\end{array}$ & -2.134 & $0.033(S)$ & $\begin{array}{l}7.0 \pm 1.8 \\
8.8 \pm 3.4\end{array}$ & -1.948 & $\begin{array}{l}0.051 \\
\text { (NS) }\end{array}$ & $\begin{array}{l}12.4 \pm 2.3 \\
13.2 \pm 2.9\end{array}$ & -1.081 & $\begin{array}{l}0.284 \\
\text { (NS) }\end{array}$ \\
\hline Dyslipidemia & $\begin{array}{l}\text { No } \\
\text { Yes }\end{array}$ & $\begin{array}{l}60(85.7 \%) \\
10(14.3 \%)\end{array}$ & $\begin{array}{l}132.1 \pm 306.4 \\
148.9 \pm 323.9\end{array}$ & -0.36 & $\begin{array}{l}0.719 \\
\text { (NS) }\end{array}$ & $\begin{array}{l}7.6 \pm 2.4 \\
6.5 \pm 1.5\end{array}$ & -1.419 & $\begin{array}{l}0.156 \\
\text { (NS) }\end{array}$ & $\begin{array}{l}12.5 \pm 2.5 \\
13.3 \pm 2.3\end{array}$ & -1.039 & $\begin{array}{l}0.302 \\
\text { (NS) }\end{array}$ \\
\hline Obesity & $\begin{array}{l}\text { No } \\
\text { Yes }\end{array}$ & $\begin{array}{l}42(60 \%) \\
28(40 \%)\end{array}$ & $\begin{array}{r}173.1 \pm 373.8 \\
76.6 \pm 148.9\end{array}$ & -0.194 & $\begin{array}{l}0.846 \\
(\mathrm{NS})\end{array}$ & $\begin{array}{l}7.3 \pm 2.6 \\
7.6 \pm 1.8\end{array}$ & -1.41 & $\begin{array}{c}0.159 \\
(\mathrm{NS})\end{array}$ & $\begin{array}{l}12.4 \pm 2.5 \\
12.9 \pm 2.3\end{array}$ & -0.936 & $\begin{array}{l}0.352 \\
\text { (NS) }\end{array}$ \\
\hline Family history & $\begin{array}{l}\text { No } \\
\text { Yes }\end{array}$ & $\begin{array}{l}67(95.7 \%) \\
3(4.3 \%)\end{array}$ & $\begin{array}{l}133.3 \pm 309.5 \\
162.7 \pm 281.7\end{array}$ & -0.288 & $\begin{array}{l}0.773 \\
(\mathrm{NS})\end{array}$ & $\begin{array}{l}7.4 \pm 2.4 \\
7.8 \pm 1.3\end{array}$ & -0.958 & $\begin{array}{l}0.338 \\
(\mathrm{NS})\end{array}$ & $\begin{array}{l}12.6 \pm 2.5 \\
12.5 \pm 1.0\end{array}$ & 0.053 & $\begin{array}{l}0.958 \\
(\mathrm{NS})\end{array}$ \\
\hline
\end{tabular}

EAT: Epicardial Adipose Tissue, PCFT: Pericoronary Fat Thickness, Ca: Calcium, HTN: Hypertension, DM: Diabetes Mellitus. 
(statistically nonsignificant) in PCFT in patients with risk factors (hypertension, DM, smoking, dyslipidemia, obesity) (Table 2).

The mean age, male gender and percent \% of patients with DM were significantly higher in group 3 patients than other groups as shown in Table 3.

Ca score was significantly higher in group $3(320 \pm 454.5)$ compared to group $2(69.4 \pm 132.8)$ and group $1(0)$. The mean epicardial adipose tissues thickness (EAT) was significantly more in group $3(8.5 \pm 3.1 \mathrm{~mm})$ compared to group 2 $(7.2 \pm 1.4 \mathrm{~mm})$ and group $1(6.2 \pm 1.2)$ Figure 2 . The mean pericoronary fat thickness (PCFT) was significantly more in group $3(14 \pm 2.4 \mathrm{~mm})$ compared to group $2(12.6 \pm 2.0 \mathrm{~mm})$ and group $1(10.8 \pm 1.7 \mathrm{~mm})$ as shown in Table 4 .

ROC curve was used to define the best cut off values of EAT and PCFT in predicting the obstructive CAD group (3) and they were $\geq 7.2$ and $12.6 \mathrm{~mm}$ for EAT and PCFT respectively with sensitivity of $67 \%$ and $72 \%$ respectively, specificity of $67.4 \%$ and $62.2 \%$ respectively, positive predictive value (PPV) of $50 \%$ and $51.4 \%$ respectively, negative predictive value (NPV) of $76.3 \%$ and $80 \%$ respectively with diagnostic accuracy of $64.3 \%$ and $65.7 \%$ respectively as shown in Figure 3 and Table 5.

Table 3. Comparison between the studied groups regarding the demographic data.

\begin{tabular}{|c|c|c|c|c|c|c|}
\hline $\begin{array}{c}\text { Demographic } \\
\text { data }\end{array}$ & All patients & $\begin{array}{l}\text { Group } 1 \\
\text { (Normal) }\end{array}$ & $\begin{array}{c}\text { Group } 2 \\
\text { (Non-obstructive) }\end{array}$ & $\begin{array}{c}\text { Group } 3 \\
\text { (Obstructive) }\end{array}$ & \multirow[t]{2}{*}{ Test } & \multirow{2}{*}{$\begin{array}{l}\text { p-value } \\
\text { (Sig.) }\end{array}$} \\
\hline Count (\%) & $70(100 \%)$ & $20(28.6 \%)$ & $25(35.7 \%)$ & $25(35.7 \%)$ & & \\
\hline \multicolumn{7}{|l|}{ Sex } \\
\hline Female & $25(35.7 \%)$ & $12(60 \%)$ & $10(40 \%)$ & $\begin{array}{c}22(88 \%) \\
3(12 \%)\end{array}$ & $11.64^{\ddagger}$ & $0.003(S)$ \\
\hline \multicolumn{7}{|l|}{ Age (years) } \\
\hline $\begin{array}{c}\text { Mean } \pm S D \\
\text { Range }\end{array}$ & $\begin{array}{c}50.6 \pm 9.3 \\
24-67\end{array}$ & $\begin{array}{c}44.6 \pm 9.3^{\circ \bullet} \\
24-58\end{array}$ & $\begin{array}{c}54.9 \pm 7.5 \\
41-67\end{array}$ & $\begin{array}{c}51.2 \pm 8.6 \\
32-67\end{array}$ & $8.43^{\AA}$ & $0.001(S)$ \\
\hline \multicolumn{7}{|l|}{$H T N$} \\
\hline & $32(45.7 \%)$ & $5(25 \%)$ & $13(52 \%)$ & $14(56 \%)$ & $4.92^{\ddagger}$ & 0.085 (NS) \\
\hline \multicolumn{7}{|l|}{$D M$} \\
\hline & $19(27.1 \%)$ & $1(5 \%)$ & $10(40 \%)$ & $8(32 \%)$ & $7.35^{\ddagger}$ & $0.025(S)$ \\
\hline \multicolumn{7}{|l|}{ Dyslipidemia } \\
\hline & $10(14.3 \%)$ & $2(10 \%)$ & $2(8 \%)$ & $6(24 \%)$ & $3.03^{\ddagger}$ & 0.219 (NS) \\
\hline \multicolumn{7}{|l|}{ Obesity } \\
\hline & $28(40 \%)$ & $9(45 \%)$ & $11(44 \%)$ & $8(32 \%)$ & $1.04^{\ddagger}$ & 0.594 (NS) \\
\hline \multicolumn{7}{|l|}{ Smoking } \\
\hline & $15(21.4 \%)$ & $2(10 \%)$ & $5(20 \%)$ & $8(32 \%)$ & $3.24^{\ddagger}$ & 0.198 (NS) \\
\hline \multicolumn{7}{|l|}{ Family history } \\
\hline & $3(4.3 \%)$ & $1(5 \%)$ & $1(4 \%)$ & $1(4 \%)$ & $0.035^{\ddagger}$ & 0.983 (NS) \\
\hline
\end{tabular}

${ }^{\mathrm{A}}$ One-way Anova test, ${ }^{\ddagger}$ Chi-square test, $\mathrm{p}<0.05$ is significant, Sig.: significance. ${ }^{\circ}$ Significant with group 2 ( $\mathrm{p}$-value $<0.001)$, ${ }^{\circ}$ Significant with group 3 ( $\mathrm{p}$ value $\left.=0.011\right)$. 
Table 4. Comparison between studied groups regarding the coronary CT angiographic data.

\begin{tabular}{|c|c|c|c|c|c|c|}
\hline Coronary CT data & All patients & Group 1 (Normal) & Group 2 (Non-obstructive) & Group 3 (Obstructive) & \multirow{2}{*}{ Test } & \multirow{2}{*}{$\begin{array}{c}\text { p-value } \\
\text { (Sig.) }\end{array}$} \\
\hline Count (\%) & $70(100 \%)$ & $20(28.6 \%)$ & $25(35.7 \%)$ & $25(35.7 \%)$ & & \\
\hline \multicolumn{7}{|l|}{ Ca score } \\
\hline$M e a n \pm S D$ & $136.5 \pm 308.4$ & $0 \pm 0$ & $69.4 \pm 132.8$ & $320 \pm 454.5$ & \multirow{2}{*}{$36.51^{\mathrm{K}}$} & \multirow{2}{*}{$<0.001$ (HS) } \\
\hline Range & $0-1697$ & 0 & $0-488$ & $0-1697$ & & \\
\hline \multicolumn{7}{|l|}{ EAT thickness (mm) } \\
\hline$M e a n \pm S D$ & $7.4 \pm 2.3$ & $6.2 \pm 1.2$ & $7.2 \pm 1.4$ & $8.5 \pm 3.1$ & \multirow{2}{*}{$8.62^{\mathrm{K}}$} & \multirow{2}{*}{$0.013(S)$} \\
\hline Range & $3.2-16$ & $3.2-9.3$ & $4.7-9.2$ & $5-16$ & & \\
\hline \multicolumn{7}{|l|}{$P C F T(\mathrm{~mm})$} \\
\hline$M e a n \pm S D$ & $12.6 \pm 2.5$ & $10.8 \pm 1.7^{\bullet \bullet}$ & $12.6 \pm 2.0^{\circ}$ & $14 \pm 2.4$ & \multirow{2}{*}{$12.76^{\mathrm{A}}$} & \multirow{2}{*}{$<0.001$ (HS) } \\
\hline Range & $7-18.1$ & $7.5-14.3$ & $8.8-17.1$ & $7-18.1$ & & \\
\hline
\end{tabular}

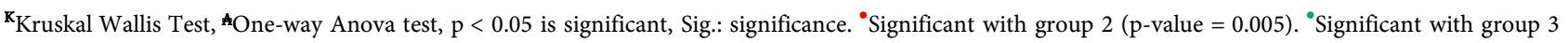
(p-value $<0.001)$. ${ }^{\circ}$ Significant with group 3 (p-value $\left.=0.024\right)$.

Table 5. EAT thickness $(\mathrm{mm})$ and PCFT $(\mathrm{mm})$ as predictors for obstructive coronary artery disease (OCAD); ROC curve analysis.

\begin{tabular}{ccccccc}
\hline Cut-off values & $\begin{array}{c}\mathrm{SN} \% \\
(95 \% \mathrm{CI})\end{array}$ & $\begin{array}{c}\mathrm{SP} \% \\
(95 \% \mathrm{CI})\end{array}$ & $\begin{array}{c}\text { PPV } \% \\
(95 \% \mathrm{CI})\end{array}$ & $\begin{array}{c}\text { NPV \% } \\
(95 \% \mathrm{CI})\end{array}$ & $\begin{array}{c}\text { Accuracy } \\
(95 \% \mathrm{CI})\end{array}$ & $\begin{array}{c}\text { AUROC } \\
(95 \% \mathrm{CI})\end{array}$ \\
\hline EAT & $64 \%$ & $64.4 \%$ & $50 \%$ & $76.3 \%$ & $64.3 \%$ & 0.645 \\
$\geq 7.2 \mathrm{~mm}$ & $(42.5-82.0)$ & $(48.8-78.1)$ & $(31.9-68.1)$ & $(59.8-88.6)$ & $(51.9-75.4)$ & $(0.472-0.770)$ \\
PCFT & $72 \%$ & $62.2 \%$ & $51.4 \%$ & $80 \%$ & $65.7 \%$ & 0.767 \\
$\geq 12.6 \mathrm{~mm}$ & $(50.6-87.9)$ & $(46.5-76.2)$ & $(33.9-68.6)$ & $(63.1-91.6)$ & $(53.4-76.7)$ & $(0.620-0.862)$ \\
\hline
\end{tabular}

EAT: Epicardial Adipose Tissue, PCFT: Pericoronary Fat Thickness, SN: Sensitivity, SP: Specificity, PPV: Positive Predictive Value, NPV: Negative Predictive Value.

\section{Pairwise Comparisons of Group}

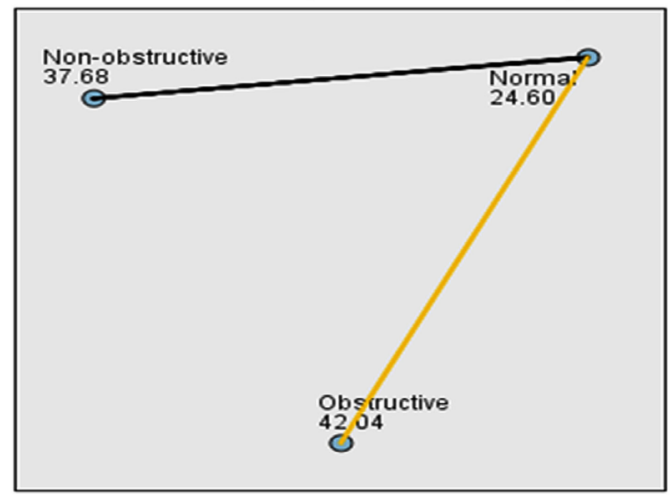

Each node shows the sample average rank of Group.

\begin{tabular}{|lrrrrr|}
\hline Sample1-Sample2 & $\begin{array}{c}\text { Teest } \\
\text { Statistic }\end{array}$ & $\begin{array}{c}\text { Std. } \\
\text { Error }\end{array}$ & $\begin{array}{c}\text { Std. Test } \\
\text { Statistic }\end{array}$ & \multicolumn{1}{c|}{ Sig. } & Adj.Sig. \\
\cline { 2 - 6 } Normal-Non-obstructive & -13.080 & 6.101 & -2.144 & 0.032 & 0.096 \\
\hline Normal-Obstructive & -17.440 & 6.101 & -2.858 & 0.004 & 0.013 \\
\hline Non-obstructive-Obstructive & -4.360 & 5.752 & -0.758 & 0.448 & 1.000 \\
\hline
\end{tabular}

Figure 2. Pairwise comparison between the studied groups regarding EAT. 


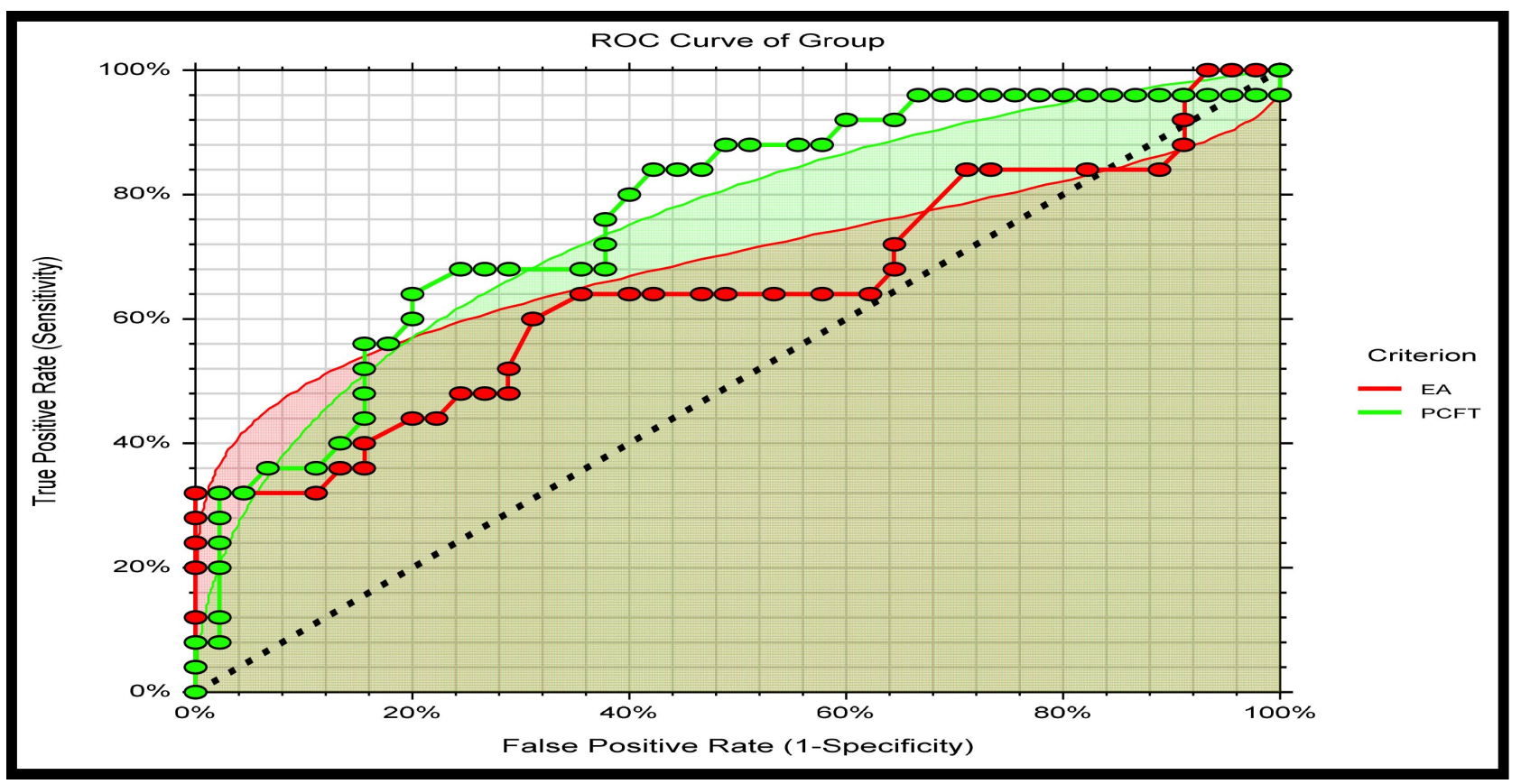

Figure 3. ROC curve for EAT and PCFT for the development of obstructive coronary artery disease.

EAT and PCFT showed statistical significance positive correlation with each other $(\mathrm{p}<0.001)$. EAT and Ca score showed statistical significance positive correlation with each other $(\mathrm{p}<0.004)$. PCFT and Ca score showed statistical significant positive correlation with each other $(\mathrm{p}<0.001)$ (Table 6).

\section{Discussion}

There is growing evidence that epicardial fat thickness and pericoronarty fat is associated with increased cardiovascular risk. Epicardial adipose tissue (EAT) is a type of visceral fat that has been found to be associated with coronary artery plaques and calcification [13]. It has been suggested that epicardial fat may exert a local paracrine effect on adjacent coronary artery segments and ensuing local inflammation and changes in plaque structure [14].

Epicardial adipose tissue secretes pro and anti-inflammatory mediators that contribute to the formation of CAD. Full understanding of the pathophysiological role of EAT thickness has led to a search for imaging methods that can provide EAT thickness measurements and detect CAD [15].

Commonly, transthoracic echocardiography (TTE) has been usually used to assess EAT thickness. [8] However, measurement of EAT using TTE has limitations. As this method is highly dependent on acoustic windows and operator experience. Also it has limited spatial resolution, which makes it challenging to differentiate between epicardial and pericardial fat. Moreover, the sole measurement of EAT around the right ventricular free wall can be unreliable, as the distribution of adipose tissue around the heart may not be uniform. In comparison to TTE, MDCT is associated with less discomfort for the patient and is capable of providing more accurate information on EAT thickness [16]. Also in 
Table 6. Correlation between Ca score, EAT and PCFT (Spearman's correlation).

\begin{tabular}{|c|c|c|c|c|c|}
\hline & & & EAT & PCFT & Ca score \\
\hline & & Correlation Coefficient & & $0.438^{\star *}$ & $0.341^{\star *}$ \\
\hline & EAT & Sig. (2-tailed) & & $<0.001$ (HS) & $0.004(S)$ \\
\hline & & $\mathrm{N}$ & & 70 & 70 \\
\hline & & Correlation Coefficient & $0.438^{* *}$ & & $0.518^{* *}$ \\
\hline \multirow[t]{5}{*}{ Spearman's rho } & PCFT & Sig. (2-tailed) & $<0.001$ (HS) & & $<0.001$ (HS) \\
\hline & & $\mathrm{N}$ & 70 & & 70 \\
\hline & & Correlation Coefficient & $0.341^{* *}$ & $0.518^{* *}$ & \\
\hline & Ca score & Sig. (2-tailed) & $0.004(S)$ & $<0.001$ (HS) & \\
\hline & & $\mathrm{N}$ & 70 & 70 & \\
\hline
\end{tabular}

our study we measured the thickness of EAT and PCF by multidetector CT because it is easier to perform and less time-consuming compared to the labor-intensive work for measurements of EAT volume. From our results we found a significant relation between the thickness of both epicardial adipose tissue thickness, pericoronary fat as well as the calcium score and the Significance of coronary artery disease with higher values in group 3 with obstructive coronary artery disease compared to group 1 and 2. Several studies showed results consistent with our findings. [12] evaluated the relationship between Epicardial adipose tissue and pericoronary fat thickness measured with 64-multidetector computed tomography. They concluded that epicardial adipose tissue and pericoronary fat thickness scores were higher in patients with obstructive coronary artery diseases. Also Aydin et al. studied also the relationship between pericoronary fat thickness and the severity of coronary artery disease. They concluded that the pericoronary fat thickness was higher in patients with coronary artery disease compared to patients without coronary artery disease [17]. Fabien A et al. e measured epicardial fat thickness by computed tomography and assessed the presence and extent of CAD by coronary angiography in participants from the prospective EVASCAN study, They found that lateral wall EAT thickness correlated with the presence and extent of angiographic CAD [18].

Quantitation of EAT may be useful, in addition to coronary artery calcium score and coronary angiography, to identify patients at risk for CAD.

We found also that EAT and PFT can be used as a predictor of obstructive coronary artery disease. The results of our study were similar to the results of the study done by Demircelik et al. [12].

In our study by using the ROC curve, we found that the best cut off values of EAT and PCFT in predicting the obstructive CAD group (3) were $\geq 7.2$ and 12.6 $\mathrm{mm}$ for EAT and PCFT respectively with sensitivity of $67 \%$ and $72 \%$ respectively, specificity of $67.4 \%$ and $62.2 \%$ respectively, positive predictive value (PPV) of $50 \%$ and $51.4 \%$ respectively, negative predictive value (NPV) of $76.3 \%$ and $80 \%$ 
respectively with diagnostic accuracy of $64.3 \%$ and $65.7 \%$ respectively. The results of our study were similar to the results of the study done by Demircelik et al. [12] who found the optimum cut-off point of PCFT for occurrence of obstructive coronary artery disease, was $13.8 \mathrm{~mm}$ with a sensitivity of $72.2 \%$ and a specificity of $68.1 \%$ and the optimum cut-off point of which EAT was $6.8 \mathrm{~cm}$ with a sensitivity of $73.5 \%$ and a specificity of $69.3 \%$.

Our study has some limitations including: limited number of patients. Only one modality was used to assess epicardial fat thickness, other studies comparing different modalities are needed.

\section{Conclusion}

Epicardial adipose tissue thickness and pericoronary fat thickness assessed by multidetector CT can be used to predict the significance of coronary artery disease.

\section{Conflicts of Interest}

The authors declare no conflicts of interest regarding the publication of this paper.

\section{References}

[1] Mazurek, T., Zhang, L., Zalewski, A., Mannion, J., Arafat, H., et al. (2003) Human Epicardial Adipose Tissue Is a Source of Inflammatory Mediators. Circulation, 108, 2460-2466. https://doi.org/10.1161/01.CIR.0000099542.57313.C5

[2] Iacobellis, G., Pistilli, D., Gucciardo, M., Leonetti, F., Miraldi, F., Brancaccio, G., et al. (2005) Adiponectin Expression in Human Epicardial Adipose Tissue in Vivo Is Lower in Patients with Coronary Artery Disease. Cytokine, 29, 251-255. https://doi.org/10.1016/j.cyto.2004.11.002

[3] Baker, A., Silva, N., Quinn, D., Harte, A., Pagano, D., Bonser, R., et al. (2006) Human Epicardial Adipose Tissue Expresses a Pathogenic Profile of Adipocytokines in Patients with Cardiovascular Disease. Cardiovascular Diabetology, 5, 1.

https://doi.org/10.1186/1475-2840-5-1

[4] Iacobellis, G. and Willens, H.J. (2009) Echocardiographic Epicardial Fat: A Review of Research and Clinical Applications. Journal of the American Society of Echocardiography, 22, 1311-1319. https://doi.org/10.1016/j.echo.2009.10.013

[5] Ahn, S., Lim, H., Joe, D., Kang, S., Choi, B., Choi, S., et al. (2008) Relationship of Epicardial Adipose Tissue by Echocardiography to Coronary Artery Disease. Heart, 94, e7. https://doi.org/10.1136/hrt.2007.118471

[6] Dey, D., Wong, N.D., Tamarappoo, B., Nakazato, R., Gransar, H., Cheng, V.Y., et al. (2010) Computer-Aided Non-Contrast CT-Based Quantification of Pericardial and Thoracic Fat and Their Associations with Coronary Calcium and Metabolic Syndrome. Atherosclerosis, 209, 136-141.

https://doi.org/10.1016/j.atherosclerosis.2009.08.032

[7] Ding, J., Hsu, F., Harris, T., Liu, Y., Kritchevsky, S., Szklo, M., et al. (2009) The Association of Pericardial Fat with Incident Coronary Heart Disease: The Multi-Ethnic Study of Atherosclerosis (MESA). The American Journal of Clinical $\mathrm{Nu}$ trition, 90, 499-504. https://doi.org/10.3945/ajcn.2008.27358 
[8] Greif, M., Becker, A., von Ziegler, F., Lebherz, C., Lehrke, M., Broedl, U.C., et al. (2009) Pericardial Adipose Tissue Determined by Dual Source CT Is a Risk Factor for Coronary Atherosclerosis. Arteriosclerosis, Thrombosis, and Vascular Biology, 29, 781-786. https://doi.org/10.1161/ATVBAHA.108.180653

[9] Mahabadi, A.A., Reinsch, N., Lehmann, N., Altenbernd, J., Kälsch, H., Seibel, R.M., et al. (2010) Association of Pericoronary Fat Volume with Atherosclerotic Plaque Burden in the Underlying Coronary Artery: A Segment Analysis. Atherosclerosis, 211, 195-199. https://doi.org/10.1016/j.atherosclerosis.2010.02.013

[10] Diamond, G.A. and Forrester, J.S. (1979) Analysis of Probability as an Aid in the Clinical Diagnosis of Coronary-Artery Disease. The New England Journal of Medicine, 300, 1350-1358. https://doi.org/10.1056/NEJM197906143002402

[11] Arbab-Zadeh, A. and Hoe, J. (2011) Quantification of Coronary Areterial Stenoses by Multidetector CT Angiography in Comparison with Conventional Angiography: Methods, Caveats and Implications. JACC: Cardiovascular Imaging, 4, 191-202. https://doi.org/10.1016/j.jcmg.2010.10.011

[12] Demircelik, M.B., Yilmaz, O.C., Gurel, O.M., Selcoki, Y., Atar, I.A., Bozkurt, A., et al. (2014) Epicardial Adipose Tissue and Pericoronary Fat Thickness Measured with 64-Multidetector Computed Tomography: Potential Predictors of the Severity of Coronary Artery Disease. Clinics, 69, 388-392. https://doi.org/10.6061/clinics/2014(06)04

[13] Ueno, K., Anzai, T., Jinzaki, M., Yamada, M., Jo, Y., Maekawa, Y., et al. (2009) Increased Epicardial Fat Volume Quantified by 64-Multidetector Computed Tomography Is Associated with Coronary Atherosclerosis and Totally Occlusive Lesions. Circulation Journal, 73, 1927-1933. https://doi.org/10.1253/circj.CJ-09-0266

[14] Rajani, R., Shmilovich, H., Nakazato, R., Nakanishi, R., Otaki, Y., Cheng, V.Y., et al. (2013) Relationship of Epicardial Fat Volume to Coronary Plaque, Severe Coronary Stenosis, and High-Risk Coronary Plaque Features Assessed by Coronary CT Angiography. Journal of Cardiovascular Computed Tomography, 7, 125-132. https://doi.org/10.1016/j.jcct.2013.02.003

[15] Jeong, J.W., Jeong, M.H., Yun, K.H., et al. (2007) Echocardiographic Epicardial Fat Thickness and Coronary Artery Disease. Circulation Journal, 71, 536-539. https://doi.org/10.1253/circj.71.536

[16] Mohammadzadeh, M., Mohammadzadeh, V., Shakiba, M., Motevalli, M., Abedini, A., Kadivar, S., Entezari, P. and Mohammadzadeh, A. (2018) Assessing the Relation of Epicardial Fat Thickness and Volume, Quantified by 256-Slice Computed Tomography Scan, with Coronary Artery Disease and Cardiovascular Risk Factors. Archives of Iranian Medicine, 21, 95-100.

[17] AydinAyşe, M.A., Alperen, K., Ahmet, K.P. and KemalAydın, F. (2015) The Relationship between Coronary Artery Disease and Epicardial Coronary Adipose Tissue Thickness. Journal of International Medical Research, 43, 17-25. https://doi.org/10.1177/0300060514558323

[18] Picard, F.A., Pascal, G., Jean-Pierre, L., Stéphane, C., Florence, L., Didier Carrié, Jean-Michel, J., Patrick, H., Ralph, N., Gilles, C. and Philippe, G. (2014) Epicardial Adipose Tissue Thickness Correlates with the Presence and Severity of Angiographic Coronary Artery Disease in Stable Patients with Chest Pain. PLoS ONE, 9, e110005. https://doi.org/10.1371/journal.pone.0110005 